Cakrawala Dini: Jurnal Pendidikan Anak Usia Dini | p-ISSN 2087-1317 | e-ISSN 2621-8321

Vol. 12. No.I Mei 2021 | Hal 83-92

\title{
PENGARUH SMART PARENTING DEMOKRATIS TERHADAP KEMANDIRIAN INISIATIF ANAK USIA 5-6 TAHUN DI PAKEL TULUNGAGUNG
}

\author{
Windi Sinansari ${ }^{1}$, Rachma Hasibuan ${ }^{2}$ \\ ${ }^{1,2}$ Universitas Negeri Surabaya
}

\begin{abstract}
The purpose of study is to determine the effect of democratic smart parenting on the independence, initiative of children aged 5-6 years old. This research is a quantitative study used survey method. The population of this study is all parents who have children aged 5-6 years old in Pakel Tulungagung Dis-trict, numbering 414. This study used cluster random sampling. The sample chosen is 10 villages from 19 villages in Pakel. 104 respondents of parents. The data collection method uses a questionnaire that is distributed via google form. The results showed that there was an effect of democratic smart parenting on the independence, initiative of children aged 5-6 years olds. That was evidenced by the the coefficient of determination ( $R$ square) was 0.512, which implied that the influence of independent variable (democratic smart parenting) to the dependent variable was children's initiative was $51.2 \%$. It was also evidenced by the results of simple linear regression analysis used SPSS version 26 application. From the results of the calculation of tcount of 10.338 compared to ttable which was 1.65993 with a sig-nificant level of 5\%, so tcount $>$ ttable then Ha accepted and Ho rejected. So it can be concluded that varia-ble $X$ has a significant effect on variable $Y$. From the results of testing was evident democratic smart parenting had an influence on the independence of initiative of children aged 5-6 years old in Pakel Sub-District Tulungagung.
\end{abstract}

Keyword: the role of parents, democratic smart parenting, independence

\begin{abstract}
Abstrak: Tujuan penelitian adalah untuk mengetahui pengaruh dari smart parenting demokratis terhadap kemandirian inisiatif anak usia 5-6 tahun. Penelitian ini merupakan penelitian kuantitatif dengan metode survey. Populasi penelitian adalah seluruh orang tua yang mempunyai anak 5-6 tahun di Keca-matan Pakel Tulungagung yang berjumlah 414 . Teknik sampel penelitian menggunakan cluster random sampling. Sampel yang dipilih yaitu 10 Desa dari 19 Desa yang ada di Pakel. Dengan total 104 responden orang tua. Metode pengumpulan data menggunakan koesioner yang dibagikan melalui google form. Hasil penelitian menunjukkan terdapat pengaruh dari smart parenting demokratis terhadap kemandirian inisiatif anak usia 5-6 tahun yang dibuktikan hasil koefisien determinasi ( $R$ square) sebesar 0,512, yang mengandung pengertian bahwa pengaruh variabel bebas (smart parenting demokratis) terhadap variabel terikat (kemandirian inisiatif anak) sebesar 51,2\%. Hal ini juga dibuktikan dengan hasil analisis regresi linier sederhana menggunakan aplikasi SPSS versi 26. Dari hasil perhitungan thitung sebesar 10,338 dibandingkan dengan ttabel yaitu 1,65993 taraf signifikan 5\%, sehingga thitung > ttabel maka Ha diterima dan Ho di tolak. Sehingga dapat ditarik kesimpulan bahwa variabel bebas $(\mathrm{X})$ terdapat pengaruh yang signifikan terhadap variabel terikat (Y). Dari hasil analisis terbukti smart parenting demokratis memiliki pengaruh terhadap kemandirian inisiatif anak usia 5-6 tahun di Kecamatan Pakel Tulungagung.
\end{abstract}

Kata Kunci: peran orang tua, smart parenting demokratis, kemandirian

\footnotetext{
' Universitas Negeri Surabaya, Email: windi.17010684005国mhs.unesa.ac.id

${ }^{2}$ Universitas Negeri Surabaya, Email: rachmahasibuan国unesa.ac.id
} 


\section{PENDAHULUAN}

Orang tua adalah sekolah dan guru pertama yang membentuk kepribadian serta karakter seorang anak, hingga nanti kepribadian yang terbentuk pada diri anak sesuai dengan yang diterapkan dan dibiasakan dalam keseharian di lingkungan keluarga. Hal ini menjadi penting karena masa anak-anak adalah masa yang sangat tepat untuk mengoptimalkan proses perkembangan kemandirian. Ketika anak memasuki awal sekolah, kemampuan anak untuk beradaptasi sudah dapat dimanfaatkan dengan baik. Namun berbeda hal dengan keadaan di lapangan. Suana \& Firdaus (2018), mengungkapkan sering ditemukan keterlambatan penyesuaian sosial dan mandiri terutama diusia awal sekolah. Masalah yang sering ditemui salah satunya kemampuan yang belum optimal dalam proses sosial mandiri di lingkungan anak. Anak belum mampu untuk mandiri dalam bersosialisasi dalam hal berinteraksi dengan teman. Sehingga anak dalam keseharian anak mengalami kendala kesiapan yang ditunjukkan dengan adanya perilaku menyimpang seperti takut ditinggal orang tua, bermain hanya sendirian, anak yang terlalu impulsif atau hiperaktif. Hasil pengamatan pada TK di Kecamatan Pakel, terdapat perbedaan tingkat kemandirian inisiatif antara anak yang diberikan kebebasan bereskpresi dengan anak yang terus menerima intruksi orang tua. Banyak ditemui orang tua yang terus ambil andil, tidak membiarkan anak bereksplorasi serta mengatur hal-hal yang anak lakukan. Berefek pada anak mengalami ketergantungan terhadap orang tua dan tidak optimalnya kemandirian inisiatif anak. Orang tua belum memahami dengan baik pengaruh pola asuh yang orang tua terapkan terhadap kemandirian inisiatif anak.

Hal ini didukung oleh penelitian Sunarty (2015) media cetak dan elektronik menampilkan dan menggambarkan perilaku anak yang sangat jauh dari perilaku mandiri. Perilaku ketergantungan dengan orang tua dicirikan dengan melihat sikap anak yang tidak bertanggung jawab atas perilaku yang dilakukan, contohnya: terlambat masuk sekolah, tidak mau masuk kelas, tidak mau belajar bila tidak diberi hadiah, belum optimalnya inisiatif anak serta belum optimalnya rasa disiplin dalam belajar. Masih banyak orang tua belum memahami serta mengetahui bahwa salah satu dari faktor eksternal dalam pembentukan kepribadian dan karakter anak adalah penerapan pola asuh yang dilakukan orang tua kepada anak. Dalam penelitian Elsa, Pramesti dan Nurul (2016) menjelaskan pola asuh berkontribusi dalam mempengaruhi kedisiplinan anak usia 4-6 tahun.

Hasibuan \& Marlita (2018) menjelaskan, ada 2 faktor terkait perkembangan anak yaitu: (1) interaksi berjalan dua arah antara anak dan orang tua; (2) stimulasi terus menerus. Sehingga pola asuh merupakan salah satu bentuk interaksi dan stimulasi dari orang tua kepada anak. Idris (2012) menjelaskan bahwa pola asuh merupakan warisan utama atau pemberian bekal orang tua kepada anak, sementara itu menurut Fathi (2011) parenting merupakan hubungan orang tua dengan anak guna memenuhi kebutuhan dalam fisik dan psikis anak.

Astuti (2013, hlm. 33) menjelaskan bahwa smart parenting demokratis merupakan aksi serta langkah cerdas diterapkan orang tua kepada anak ysng bertujuan untuk melindungi, merawat, mengajari, mendisiplinkan dan memberi teladan. Dalam bertindak dengan lingkungan, orang tua terkadang memiliki suatu kecenderungan untuk mempengaruhi anak, baik dalam tindakan, cara berbicara, pengetahuan, maupun pola hidup. Sedangkan menurut Teviana \& Yusiana (2012), pola asuh smart parenting demokratis akan mewujudkan anak yang memiliki kreatif, jiwa mandiri, proaktif dan tanggungjawab. Smart parenting demokratis merupakan strategi 
yang digunakan dalam mendidik anak. Dimana orang tua merupakan sekolah dan guru pertama yang anak miliki untuk mengarahkan, mengajar, membina, serta membimbing anak. Jailani (2014, hlm. 248) mengungkapkan, sama halnya dengan pendidikan dalam keluarga. Pendidikan dalam keluarga adalah usaha orang tua dalam membiasaankan dan membimbing untuk mengoptimalkan perkembangan pribadi seorang anak.

Suyanto (2010, hlm. 94) menjelaskan pola asuh demokratis mempunyai ciri yakni: (1) adanya kerjasama orang tua dengan anak; (2) kontrol orang tua tidak kaku. orang tua memberikan penjelasana dan diskusi untuk berkomunikasi dan bermusyawarah; (3) adanya sikap terbuka memberikan pengarahan dan pilihanpilihan kepada anak; dan (4) adanya penguatan untuk setiap kemampuan anak. Hal ini juga selaras dengan yang Fathi (2011) ungkapkan, pola asuh demokratis mempuyai ciri yaitu: (1) orang tua berdiskusi dengan anak, adanya kerjasama antara anak dengan orang tua; (2) orang tua mengenal keberadaan anak; (3) orang tua memberikan kesempatan anak untuk tidak terus bergantung pada orang tua (anak dilatih belajar mandiri) di bawah pengawasan orang tua.

Sejalan dengan penelitian yang dilakukan Sunarty (2015) bahwa penerapan model pola asuh yang tepat dapat meningkatkan kemandirian serta mengubah pandangan, tindakan dan sikap orang tua kepada anak. Pada saat yang bersamaan, perubahan yang dilakukan orang tua terhadap anak akan dirasakan baik bagi diri anak, sehingga terciptalah komunikasi yang baik, saling mendengarkan, kerjasama dan keterbukaan orang tua dengan anak. Perbedaan dalam perkataan, tingkah laku dan perilaku orang tua dalam komunikasi, transaksi atau interaksi membuat anak semakin memperhatikan dan mempercayai aktivitas yang anak lakukan, hingga anak dapat leluasa dalam mengambil tanggung jawab dan keputusan. Hal ini sejalan dengan Barnes (2016), berpendapat bahwa kerjasama orang tua utamanya ayah berperan penting dalam perkembangan prestasi anak, seperti teori dari Eriksson, Vygotsky, dan Bronfenbrenner. Dijelaskan pula oleh Yamin, Martinis dan Sanan, (2012, hlm. 61) kemandirian anak dapat diawali dari lingkungan keluarga. Hal ini yang membuat tingkat kemandirian setiap anak berbeda satu sama lain. Karena tiap anak pasti tumbuh didalam lingkungan keluarga yang berbeda-beda. Perbedaan lingkungan keluarga menjadi salah satu faktor yang akan mempengaruhi kemandirian.

Muhadi (2015) mengungkapkan peran orang tua sangat penting guna mendorong kemandirian anak agar terbentuk anak mandiri. Pola asuh demokratis memegang peranan yang sangat penting disini, karena pola asuh jenis ini merupakan gambaran bagaimana interaksi orang tua dengan anak dikegiatan sehari-hari. Kegiatan pola asuh akan mengasah kemampuan pribadi anak untuk melakukan aktivitas di lingkungan keluarga. Agency, Beranda dan Tridhonanto (2014) menjelaskan pola asuh demokratis atau smart parenting demokratis merupakan salah satu model pola asuh yang dimana orang tua menginspirasi dan membimbing anak lebih mandiri, namun masih dalam batasan dan pengawasan orang tua. Orang tua selalu rendah hati, penuh cinta kasih dan perhatian.

Orang tua harus memberikan ruang bagi anak-anak untuk berbicara tentang harapan anak. Hal ini didukung oleh Tabi'in (2020) untuk membentuk kemandirian anak, langkah yang tepat perlu diambil dan persiapan yang cermat harus dilakukan untuk membantu anak mencapai kemandirian. Bagaimana orang tua menstimulasi anak agar mandiri, misalnya membiasakan anak makan sendiri atau tidak, membiasakan anak memilih apapun sesuai keinginan anak tanpa harus diatur. Hal tersebut sangat 
penting untuk membentuk kepribadian anak.

Menurut Jojon (2017) pola asuh demokratis atau smart parenting demokratis merupakan salah satu cara pola asuh dimana memberi kebebasan anak namun dalam pengawasan orang tua. Anak akan cenderung bebas melakukan hal yang anak ingin kembangkan. Dampaknya anak-anak akan lebih bertanggung jawab atas konsekuensi yang diterima dimasa depan, menjadi pemberani, memiliki kepercayaan diri tinggi, tidak tergantung pada orang tua serta bersikap ceria. Sehingga tumbuh kembang anak akan lebih baik. Utami (2016) berpendapat bahwa pola asuh dipengaruhi oleh beberapa faktor, tentunya hal yang paling utama mempengaruhi pola asuh anak adalah orangtua.

Ki Hajar Dewantara berpendapat bahwa kemandirian adalah orang yang merdeka, secara spiritual dan psikis mandiri dari orang lain berdasarkan kekuatan sendiri. Suryono (2013) menungkapkan meskipun sekolah dan lingkungan juga memiliki peran dalam memberi kesempatan anak untuk mandiri, keluarga tetap menjadi pilar utama dan paling pertama dari membentuk kemandirian pada diri anak.

Berdasarkan penjelasan diatas, menunjukkan pentingnya peran orang tua untuk memberikan pola asuh yang tepat serta sesuai untuk anak. Penelitian ini akan mengkaji tentang pengaruh pengaruh smart parenting demokratis terhadap kemandirian inisiatif anak usia 5-6 tahun di Kecamatan Pakel Tulungagung.

\section{METODOLOGI PENELITIAN}

Dalam penelitian, peneliti menggunakan data penelitian kuantitatif, dangan metode survey. Populasi penelitian yakni keseluruhan atau seluruh orang tua yang mempunyai anak usia 5-6 tahun di Kecamatan Pakel Tulungagung. Jumlah populasi penelitian sebanyak 414 yang tersebar pada 19 desa di Kecamatan Pakel Tulungagung.

Teknik pengambilan sampel yang dipakai dalam penelitian yakni, cluster random sampling. Peneliti menggunakan teknik ini karena populasi yang terdiri seluruh orang tua yang mempunyai anak usia 5-6 tahun tersebar di Kecamatan Pakel. Kecamatan Pakel Tulungagung terdiri dari 19 Desa. Kemudian berdasarkan acak dari 19 desa, diperoleh sebanyak 10 desa, dimana penentuan jumlah ini didasari atas pertimbangan bahwa pada 10 desa yang diambil orang tua mempunyai anak usia 5-6 tahun sesuai yang dibutuhkan oleh peneliti.

Pengumpulan data pada penelitian memanfaatkan angket atau kuesioner serta dokumentasi. Instrumen penelitian dalam penelitian ini menggunakan kuesioner yang disebarkan kepada orang tua dengan teknik pengisian kuesioner melalui google form. Penelitian ini memiliki dua variabel yakni, variabel bebas (independen) adalah smart parenting demokratis dan variabel terikat (dependen) adalah kemandirian inisiatif anak dengan. Penelitian menggunakan skala pengukuran yaitu skala likert.

Penghitungan data pada penelitian menggunakan uji regresi linier sederhana. Analisis perhitungan uji regresi yang melibatkan beberapa perhitungan statistika yakni, uji signifikansi (uji-t, ujiF), serta penentuan hipotesis. Teknik yang digunakan adalah regresi linier sederhana.

\section{HASIL PENELITIAN DAN PEMBAHASAN}

Dari hasil penelitian yang dilakukan dengan jumlah sampel 104 orang tua di Kecamatan Pakel Tulungagung yang memiliki anak usia 5-6 tahun melalui penyebaran kuisioner melalui google form, hasil penelitian merujuk pada rumusan masalah, yaitu apakah ada pengaruh antara smart parenting demokratis terhadap kemandirian inisiatif anak usia 5-6 Tahun di Kecamatan Pakel 
Tulungagung.

Uji validasi pada butir item pertanyaan dari smart parenting demokratis (X) variabel bebas dan kemandirian inisiatif $(\mathrm{Y})$ variabel terikat dinyatakan valid. Dari semua butir item pertanyaan tidak ada butir item yang dinyatakan gugur. Dalam uji validitas nilai $r_{\text {hitung }}$ pada setiap butir item pertanyaan $>$ dari $\mathbf{r}_{\text {tabel }}(0,1927)$. Pada tabel dapat dilihat nilai $r_{\text {hitung }}>r_{\text {tabel }}(0,1927)$, sehingga data yang didapat pada setiap butir item pertanyaan dinyatakan valid. Dengan menggunakan aplikasi IBM SPSS versi 26 untuk menguji validasinya.

Dalam uji reliabilitas pada penelitian menggunakan rumus cronbach's alpha yang menyatakan hasil perhitungan sebagai berikut:

Tabel 1. Uji Reliabilitas

\begin{tabular}{ccc}
\hline Variabel & $\begin{array}{c}\text { Koefisien } \\
\text { Cronbach's } \\
\text { Alpha }\end{array}$ & Keputusan \\
\hline $\begin{array}{c}\text { Smart } \\
\text { parenting } \\
\text { demokratis }\end{array}$ & 0,870 & Reliabel \\
\hline $\begin{array}{c}\text { Kemandirian } \\
\text { Inisiatif }\end{array}$ & 0,913 & Reliabel \\
\hline (Sumber: Output data IBM SPSS Versi 26)
\end{tabular}

Hasil dari uji reliabilitas menunjukkan bahwa 0,60 dengan interpretasi sedang. Hasil uji reliabilitas diatas menunjukkan bahwa antara 0,800,100 sehingga terbukti bahwa reliabel sangat tinggi. Dalam hasi pengisian kuesioner pada google form rata-rata jawaban responden pada tiap indikator menyatakan hasil perhitungan sebagai berikut:

Tabel 2. Hasil Rata-Rata Pengisian Jawaban Kuesioner Variabel Smart Parenting Demokratis $(X)$

\begin{tabular}{|c|c|c|c|}
\hline No & Indikator & $\begin{array}{l}\text { Nomo } \\
\text { r Item }\end{array}$ & $\begin{array}{c}\text { Rata- } \\
\text { rata }\end{array}$ \\
\hline 1. & $\begin{array}{l}\text { Adanya kerjasama } \\
\text { orang tua dan anak. }\end{array}$ & $\begin{array}{l}\mathrm{X} 1- \\
\mathrm{X} 6\end{array}$ & 3.4904 \\
\hline 2. & $\begin{array}{l}\text { Kontrol orang tua } \\
\text { yang tidak kaku. } \\
\text { (Menggunakan } \\
\text { penjelasan dan }\end{array}$ & $\begin{array}{l}\text { X7- } \\
\mathrm{X} 12\end{array}$ & 3.5000 \\
\hline
\end{tabular}

\begin{tabular}{|c|c|c|c|}
\hline & $\begin{array}{l}\text { diskusi dalam } \\
\text { berkomunikasi) }\end{array}$ & & \\
\hline 3. & $\begin{array}{l}\text { Adanya sikap } \\
\text { terbuka } \\
\text { memberikan } \\
\text { pengarahan dan } \\
\text { pilihan-pilihan } \\
\text { kepada anak. } \\
\end{array}$ & $\begin{array}{c}\text { X13- } \\
\text { X18 }\end{array}$ & 3.5577 \\
\hline 4. & $\begin{array}{lr}\text { Adanya } & \text { penguatan } \\
\text { untuk } & \text { setiap } \\
\text { kemampuan } & \text { anak. } \\
\text { Pengakuan } & \text { secara } \\
\text { individu r ran } & \text { dan } \\
\text { apresiasi } & \text { pecapaian } \\
\text { anak. } & \end{array}$ & $\begin{array}{l}\text { X19- } \\
\text { X24 }\end{array}$ & 3.5353 \\
\hline 5. & $\begin{array}{l}\text { Orang tua mem- } \\
\text { berikan kesempatan } \\
\text { untuk tidak bergan- } \\
\text { tung pada orang tua } \\
\text { (anak dilatih belajar } \\
\text { mandiri) di bawah } \\
\text { pengawasan orang } \\
\text { tua }\end{array}$ & $\begin{array}{l}\text { X25- } \\
\text { X30 }\end{array}$ & 3.4936 \\
\hline
\end{tabular}

Tabel 3. Hasil Rata-Rata Pengisian Jawaban Kuesioner Variabel Kemandirian Inisiatif

\begin{tabular}{lccl}
\multicolumn{4}{c}{$(\mathrm{Y})$} \\
\hline No & Indikator & $\begin{array}{c}\text { Nomor } \\
\text { Item }\end{array}$ & $\begin{array}{l}\text { Rata- } \\
\text { rata }\end{array}$ \\
\hline 1. & $\begin{array}{c}\text { Mengambil } \\
\text { inisiatif untuk } \\
\text { bertindak }\end{array}$ & $\begin{array}{c}\text { Y1- } \\
\text { Y12 }\end{array}$ & 3.4559 \\
& & \\
\hline 2. & $\begin{array}{c}\text { Mengendalikan } \\
\text { sendiri kegiatan } \\
\text { yang dilakukan }\end{array}$ & $\begin{array}{c}\text { Y13- } \\
15\end{array}$ & 3.4776 \\
\hline $3 . \quad \begin{array}{c}\text { Meningoptimalka } \\
\text { n kemampuan }\end{array}$ & Y16- & 3.4615 \\
yang dimiliki & & \\
\hline $4 . \quad \begin{array}{c}\text { Menghargai hasil } \\
\text { karya sendiri }\end{array}$ & Y28- & 3.5352 \\
& Y30 & \\
\hline
\end{tabular}

(Sumber: Output data IBM SPSS Versi 26)

Skala pengukuran yang digunakan yaitu skala likert. Dengan ketetapan pemberian skor pada tiap jawaban yang diberikan oleh responden. Skor terbesar yakni 4 diperoleh apabila respondenm enjawab selalu, skor 3 diperoleh apabila responden menjawab sering, skor 2 diperoleh apabila responden menjawab kadang-kadang dan skor 1 diperoleh apabila responden menjawab tidak pernah. Hasil ini menunjukan rata-rata responden memberi nilai 3 pada tiap item pertanyaan. Yang artinya orang tua sering 
melakukan pernyataan-pernyataan pada tiap indikator varibel $\mathrm{X}$ dan $\mathrm{Y}$.

Berdasarkan hasi uji asumsi klasik yang terdiri dari uji normalitas, uji linieritas, serta uji homogenitas menunjukkan hasil bahwa data dari persamaan model analisis regresi sudah memenuhi syarat teoristik statistik. Maka analisis regresi linier sederhana dapat digunakan untuk menjawab suatu masalah dan menguji hipotesis. Dari hasil analisis regresi linier sederhana, yang dihasilkan dapat digunakan untuk menjawab permasalahan serta menguji hipotesis untuk mengetahui pengaruh dari smart parenting demokratis terhadap kemandirian inisiatif anak usia 5-6 tahun. Hasil pengujian analisis regresi linier sederhana, sebagai berikut:

Tabel 4. Analisis Regresi Linier Sederhana

\begin{tabular}{|l|l|l|l|l|l|}
\hline Model & B & $\begin{array}{l}\text { Std. } \\
\text { Erro } \\
\text { r }\end{array}$ & $\begin{array}{l}\text { Bet } \\
\text { a }\end{array}$ & t & Sig. \\
\hline $\begin{array}{l}\text { Nilai } \alpha / \\
\text { konstanta }\end{array}$ & $\begin{array}{l}13.89 \\
7\end{array}$ & 8.700 & & 1.597 & $\begin{array}{l}.11 \\
3\end{array}$ \\
\hline $\begin{array}{l}\text { Smart } \\
\begin{array}{l}\text { Parenting } \\
\text { Demokrati } \\
\text { s }\end{array}\end{array}$ & .851 & .082 & .715 & $\begin{array}{l}10.33 \\
8\end{array}$ & $\begin{array}{l}.00 \\
0\end{array}$ \\
\hline \multicolumn{7}{|l|}{ a. Dependent Variable: Kemandirian Inisiatif } \\
\hline
\end{tabular}

(Sumber: Output data IBM SPSS Versi 26)

Dari hasil analisis data dapat diperoleh, jika $t_{\text {hitung }}$ lebih besar dari $t_{\text {tabel }}$ maka Ha diterima dan Ho ditolak. Dari penjabaran hasil perhitungan data diperoleh $t_{\text {hitung }}$ sebesar 10,338 dibandingkan dengan $t_{\text {tabel }}$ yaitu 1,65993 taraf signifikan 5\%, sehingga $t_{\text {hitung }}>t_{\text {tabel }}$, maka artinya Ha diterima dan Ho ditolak. Dapat diartikan pula menolak Ho (hipotesisi nol) dan menerima $\mathrm{Ha}$ (hipotesis alternatif). Sehingga diperoleh kesimpulan bahwa variabel smart parenting demokratis (X) terdapat pengaruh yang signifikan terhadap variabel kemandirian inisiatif $(\mathrm{Y})$. Dari hasil analisis data dan pengujian hipotesis terbukti bahwa "Ada pengaruh antara smart parenting demokratis terhadap kemandirian inisiatif anak usia 5-6 tahun di Kecamatan Pakel Tulungagung".

Untuk mengetahui berapa besarnya pengaruh pengaruh antara smart parenting demokratis terhadap kemandirian inisiatif anak usia 5-6 tahun di Kecamatan Pakel Tulungagung pada analisis regresi linier sederhana diiperoleh nilai Koefisien Determinasi ( $R$ Square). Nilai Koefisien Determinasi ( $R$ Square) menunjukkan besaran kontribusi pengaruh yang diberikan.

Tabel 5. Hasil Koefisien Determinasi

\begin{tabular}{|l|l|l|l|l|}
\hline Model & $\mathbf{R}$ & $\begin{array}{l}\mathbf{R} \\
\text { Square }\end{array}$ & $\begin{array}{l}\text { Adjusted } \\
\mathbf{R} \\
\text { Square }\end{array}$ & $\begin{array}{l}\text { Std. } \\
\text { Error of } \\
\text { the } \\
\text { Estimate }\end{array}$ \\
\hline $\mathbf{1}$ & $.715^{\mathrm{a}}$ & .512 & .507 & 5.72917 \\
\hline $\begin{array}{l}\text { a. Predictors: (Constant), Smart Parenting } \\
\text { Demokratis }\end{array}$ \\
\hline
\end{tabular}

(Sumber: Output data IBM SPSS Versi 26)

Tabel di atas menjelaskan besar nilai korelasi atau hubungan (R) yaitu sebesar 0,715. Dari output data diperoleh koefisien determinasi atau ( $\mathrm{R}$ square) sebesar 0,512, mengandung pengertian bahwa pengaruh variabel bebas (smart parenting demokratis) terhadap variabel terikat (kemandirian inisiatif anak) adalah sebesar 51,2\% sedangkan sisanya sebesar $48,8 \%$ dijelaskan oleh variabel bebas lain yang tidak termasuk dalam penelitian ini.

Hasil penelitian yang dilakukan di Kecamatan Pakel Tulungagung menunjukan penerapan smart parenting demokratis menunjukan anak lebih berani menentukan pilihan sendiri, anak berani mengutarakan pendapat, anak berani menunjukkan kreativitas dan inisiatif. Hal tersebut ditunjukan dengan hasil nilai rata-rata indikator yang menunjukan anak mengambil inisiatif untuk bertindak sebesar 3.4559. Yang artinya anak sering melakukan tidakan-tindakan yang menunjukan rasa kemandirian inisiatif. Orang tua yang membebaskan anak untuk memilih sesuatu yang ingin anak lakukan. Hal ini juga ditunjukan dengan hasil nilai rata-rata indikator pada poin orang tua 
memberikan kebebasan kepada anak untuk tidak bergantung pada orang lain (anak dilatih belajar mandiri) menunjukan nilai rata-rata 3.4936. Yang artinya anak sering melakukan tidakan-tindakan yang membuat anak bebas memilih hal ingin anak lakukan. Adanya sikap terbuka diantara orang tua dan anak dalam keseharian menjadi jembatan komunikasi yang baik antara anak dan orang tua.

Dalam smart parenting demokratis yang diterapkan menunjukan sikap orang tua membimbing dan mengarahkan anak namun tetap mendengarkan hal yang anak inginkan orang tua. Hal ini mendukung pernyataan Sunarty (2014) bahwa penerapan model pola asuh yang tepat dapat meningkatkan kemandirian serta mengubah pandangan, tindakan dan sikap orang tua kepada anak. Pada saat yang bersamaan, perubahan yang dilakukan orang tua terhadap anak akan dirasakan baik bagi diri anak, sehingga terciptalah komunikasi yang baik, saling mendengarkan, kerjasama dan keterbukaan orang tua dengan anak. Perbedaan dalam perkataan, tingkah laku dan perilaku orang tua dalam komunikasi, transaksi atau interaksi membuat anak semakin memperhatikan dan mempercayai aktivitas yang anak lakukan, hingga anak dapat leluasa dalam mengambil tanggung jawab dan keputusan. Astuti (2013, hlm. 33) mengatakan smart parenting demokratis merupakan aksi serta langkah cerdas diterapkan orang tua kepada anak ysng bertujuan untuk melindungi, merawat, mengajari, mendisiplinkan dan memberi teladan. Dalam bertindak dengan lingkungan, orang tua terkadang memiliki suatu kecenderungan untuk mempengaruhi anak, baik dalam tindakan, cara berbicara, pengetahuan, maupun pola hidup.

Penelitian ini juga menunjukan tindakan smart parenting demokratis orang tua kepada anak seperti pembiasaan yang diberikan oleh orang tua pada anak terjadi secara berulang pada keseharian anak sehingga menjadi sebuah kebiasaan.
Kebiasaan tersebut membuat anak memiliki kemandirian dalam berinisiatif melakukan sesuatu dalam setiap kegiatan anak. Hal ini dibuktikan dengan dimensi anak dapat memberdayakan kemampuan yang dimiliki yang berisikan indikator anak mampu melakukan keterampilan aktivitas sehari-hari, anak mampu memahami peraturan yang berlaku, anak berperilaku sopan dan santun. Anak dapat menyesuaikan diri dengan lingkungan memiliki nilai rata-rata 3.4615 yang artinya kebiasaan orang tua yang membiarkan anak melakukan tanggungjawab sendiri contohnya, anak merapikan tempat tidur sendiri, memakai baju sekolah sendiri, memilih mainan sendiri, menutarakan pendapatn bila tidak sesuai yang anak inginkan, membuang sampah pada tempat sampah setelah memakan sesuatu. Mempengaruhi kemandirian inisiatif anak dalam keseharian anak.

Hal ini selaras dengan pernyataan Tabi'in (2020) untuk membentuk kemandirian anak, langkah yang tepat perlu diambil dan persiapan yang cermat harus dilakukan untuk membantu anak mencapai kemandirian. Bagaimana orang tua menstimulasi anak agar mandiri, misalnya membiasakan anak makan sendiri atau tidak, membiasakan anak memilih apapun sesuai keinginannya atau harus diatur. Hal tersebut sangat penting untuk membentuk kepribadian anak. Sejalan dengan hal tersebut Teviana \& Yusiana (2012), mengatakan pola asuh smart parenting demokratis akan mewujudkan anak yang memiliki kreatif, jiwa mandiri, proaktif dan tanggungjawab. Smart parenting demokratis merupakan strategi yang digunakan dalam mendidik anak. Dimana orang tua merupakan sekolah dan guru pertama yang anak miliki untuk mengarahkan, mengajar, membina, serta membimbing anak.

Hasil penelitian juga menunjukan tindakan smart parenting demokratis yang diterapkan orang tua pada anak, yaitu 
mendengarkan pendapat anak, memberikan ruang bagi anak untuk melakukan hal yang diinginkan, membebaskan anak melakukan sesuatu hal namun masih dalam pengawasan orang tua serta memberikan dorongan dan dukungan pada anak setiap anak melakukan sesuatu. Indikator tersebut memiliki nilai rata-rata 3.5, mengartikan bahwa orang tua sering berdiskusi dengan anak, orang tua juga sering mendengarkan pendapat anak. Hal tersebut mempengaruhi kemandirian inisiatif anak dalam melakukan sesuatu. Hal tersebut dibuktikan pada indikator anak mampu menghargai hasil karya yang memiliki nilai rata-rata 3.5. Yang artinya orang tua menyadari anak sering menunjukan perilaku tersebut,

Sesuai dengan hasil tersebut menunjukan dalam penerapan smart parenting demokratis anak lebih percaya diri dalam melakukan sesuatu, anak lebih menghargai hasil karya anak, anak juga memiliki tanggungjawab dan inisiatif dalam kegiatan yang anak lakukan. Hal ini diperkuat dengan pendapat Wiyani \& Ratri (2014) bahwa cinta serta kasih sayang yang diberiakan orang tua untuk anak harus dioptimalkan karena cinta serta kasih sayang berpengaruh dalam kemandirian anak. Namun bila cinta serta kasih sayang yang didapatkan oleh anak berlebihan akan berdampak pada kemandirian anak yang tidak optimal. Hal itu dapat diatasi apabila pola komunikasi dan interaksi yang baik dan berjalan dua arah dimiliki oleh anak dan orang tua. Hal ini sejalan dengan yang dijelaskan Muhadi (2015) peran orang tua sangat penting guna mendorong kemandirian anak agar terbentuk anak mandiri. Pola asuh demokratis memegang peranan yang sangat penting disini, karena pola asuh jenis ini merupakan gambaran bagaimana interaksi orang tua dengan anak dikegiatan sehari-hari. Kegiatan pola asuh akanmengasah kemampuan pribadi anak untuk melakukan aktivitas di lingkungan keluarga. Jika orang tua berhasil menerapkan hal ini, maka tentunya akan mendorong anak untuk mandiri.

Smart parenting demokratis memiliki pengaruh yang besar terhadap kemamampuan inisiatif 5-6 tahun di Kecamatan Pakel Tulungagung yaitu lebih dari $50 \%$. Hasil perhitungan data diperoleh bahwa pengaruh variabel smart parenting demokratis (X) terhadap kemandirian inisiatif anak (Y) sebesar $51,2 \%$ dan sisanya yaitu $48,8 \%$ dipengaruhi oleh faktor yang tidak termasuk dalam penelitian. Faktor-faktor yang dimaksud dapat berasal dari dalam diri anak (internal) maupun luar diri anak (ekternal). Hal tersebut menunjukan pemberian pola asuh yang berbeda pada keluarga menghasilkan tingkat kemandirian inisiatif yang berbeda pada anak.

Kemandirian inisiatif anak dapat dipengaruhi oleh faktor yang ada dalam diri anak. Faktor internal terdiri dari dua hal yaitu keadaan fisik dan keadaan psikologis. Fisik berkaitan dengan keadaan tubuh, anak yang tubuhnya sehat dan prima biasanya lebih mandiri karena anak mampu melakukan berbagai aktivitas sendiri dengan maksimal. Berbeda apabila anak yang sedang sakit, anak akan lebih bergantung kepada orang laincontohnya orang tua dalam melakukan kegiatan-kegiatan anak. Sedangkan psikologi berkaitan dengan kemampuan kognitif yang dimiliki anak. Anak yang mempunyai kemampuan kognitif yang baik akan mampu untuk mengatasi serta bertanggung jawab pada masalahnya sendiri tanpa meminta bantuan dari orang lain. Faktor kedua adalah faktor eksternal bersumber dari luar diri anak. Faktor eksternal terdiri atas rasa cinta hal ini dapat anak peroleh dari orang tua, teman maupun kerabat. Lingkungan sendiri juga faktor yang membentuk kepribadian anak karena anak tidak hanya bertemu dengan orang tua namun anak pergi bersekolah dan bertemu orang-orang baru, serta perhatian orangtua kepada anak. Hal ini muncul melalui pola asuh orang tua 
kepada anak. Pola asuh sendiri merupakan interaksi yang dilakukan orang tua dengan anak, sikap yang ditunjukan pada anak, serta berbagai aturan yang ditetapkan orang tua.

Dalam penelitian pola asuh yang di terapkan yaitu pola asuh smart parenting demokratis merupakan cara orang tua memberi perhatian dan cinta kasih kepada anak, memberikan tanggungjawab pada anak, membiasakan anak terbuka dengan orang tua, memberi kepercayaan anak untuk melakukan hal yang anak inginkan namun tentu dengan pengawasan orang tua. Pemberian batasan pada anak melalui komunikasi dan diskusi antara anak dan orang tua. Hal ini selaras dengan yang pernyatan Wiyani (dalam Utami, 2016) Kemandirian anak sendiri dipengaruhi oleh beberapa faktor, yang pertama faktor internal (berasal dari dalam diri anak) dan kedua yaitu, faktor eksternal (berasal dari luar diri anak). Faktor internal terdiri dari dua aspek yakni fisik dan psikologis. Faktor kedua yakni faktor eksternal. Faktor ekternal terdiri dari cinta, lingkungan anak, dan perhatian orang tua, pola asuh orangtua didalam keluarga, serta pengalaman hidup.

\section{KESIMPULAN}

Berdasarkan hasil penelitian dan pembahasan, maka dapat ditarik kesimpulan bahwa smart parenting demokratis berpengaruh terhadap kemandirian inisiatif anak. Setelah menganalisis data hasil dari Uji t peneliti menyimpulkan bahwa hasil pengujian hipotesis tersebut terbukti ada pengaruh antara smart parenting demokratis terhadap kemandirian inisiatif anak usia 5-6 tahun di Kecamatan Pakel Tulungagung. Hasil tersebut juga menyatakan ada pengaruh variabel smart parenting demokratis terhadap kemandirian inisiatif anak sebesar lebih dari $50 \%$ yaitu $51 \%$ di Kecamatan Pakel Tulungagung

\section{DAFTAR PUSTAKA}

Agency, Beranda dan Tridhonanto, A. (2014). Mengembangkan Pola Asuh Demokratis.

Astuti, H.Y. (2013). Smart Parenting: Upaya Peningkatan Kemampuan Kognitif Dan Kreativitas Anak di Kelurahan Banjarjo Boja Kendal. Rekayasa, 11(2), 117-126.

Barnes, C. (2016). The Relationship Between Male Involvement in Early Childhood Education and Student Academic Achievement. ProQuest Dissertations and Theses, 131.

Elsa, D., Pramesti,. Nurul, K. (2016). Pengaruh Pola Asuh Otoriter Terhadap Kedisiplinan Anak Usia 46 Tahun. Jurnal PAUD Teratai, Vol 5, No, 4-7.

Fathi. (2011). Mendidik Anak dengan Alqu'an Sejak Janin. Bandung.

Hasibuan, R., \& Marlita, N. A. (2018). Parenting in Day Care to Develop Autonomy and Social-Emotional Ability in Children Ages 2-3 Year. 249(Secret), 261-268. doi: 10.2991/secret-18.2018.44

Idris, M. H. (2012). Pola Asuh Anak, Melejitkan Potensi dan Prestasi Sejak Usia Dini.

Jailani, M. S. (2014). Teori Pendidikan Keluarga dan Tanggung Jawab Orang Tua dalam Pendidikan Anak Usia Dini. Nadwa, 8(2), 245. doi: 10.21580/nw.2014.8.2.580

Jojon, D. (2017). Hubungan Pola Asuh Over Protective orang Tua Terhadap Perkembangan Anak Usia Sekolah di SDN Tlogomas 1 kecematan Lowokwaru Malang. Nursing News, 2, 524-535.

Muhadi, A. I. (2015). Hubungan pola asuh demokratis orang tua terhadap kemandirian anak di taman kanakkanak El Hijaa Tambak Sari Surabaya. Jurnal Pendidikan Islam, 4(1), 1689-1699.

Suana, S., \& Firdaus, F. (2018). Pola Asuh Orangtua Akan Meningkatkan Adaptasi Sosial Anak Prasekolah Di 
Ra Muslimat $\mathrm{Nu} 202$ Assa'Adah Sukowati Bungah Gresik. Journal of Health Sciences, 7(2), 180-185. doi: 10.33086/jhs.v7i2.509

Sunarty, K. (2015). Implementasi Model Pola Asuh Orangtua. Journla of Educational Science and Technology, 1, 39-53.

Suryono, Y. (2013). Pudarnya Kemandirian Bangsa: Adakah Peran Pendidikan dan Ilmu Pendidikan. Yogyakarta.

Suyanto. (2010). Pendidikan Karakter (Teori \& Aplikasi ). Jakarta: Rineka Cipta.

Tabi'in, A. (2020). Pola Asuh Demokratis sebagai Upaya Menumbuhkan Kemandirian Anak di Panti Asuhan Dewi Aminah. KINDERGARTEN: Journal of Islamic Early Childhood Education, 3(1), 30. doi: 10.24014/kjiece.v3i1.9581

Teviana, F., \& Yusiana, M. A. (2012). Pola asuh orang tua terhadap tingkat kreativitas anak. Jurnal STIKES, 5(1), 48-60.

Utami, C. H. (2016). Hubungan Pola Asuh Autoritatif Dengan Kemandirian Anak Correlation of Authoritative Parenting Style With Kindergarten Child. 904-917.

Wiyani, N. A., \& Ratri, R. K. (2014). Bina karakter anak usia dini: panduan orangtua \& guru dalam membentuk kemandirian \& kedisiplinan anak usia dini. Yogyakarta: Ar-ruzz Media.

Yamin, Martinis dan Sanan, J. S. (2012). Panduan PAUD. 